\title{
Life-history studies on infrapopulations of Mazocraes alosae (Monogenea) parasitising Alosa immaculata (Actinopterygii) in the northern Black and Azov Seas
}

\author{
Mariana P. Plaksina ${ }^{1}$, David I. Gibson ${ }^{2} \mathbb{D}$ and Evgenija V. Dmitrieva ${ }^{3}$ \\ ${ }^{1}$ Murmansk Marine Biological Institute, Murmansk, Russia; \\ ${ }^{2}$ Department of Life Sciences, Natural History Museum, London, UK; \\ ${ }^{3}$ A.O. Kovalevsky Institute of Biology of the Southern Seas, Moscow, Russia
}

\begin{abstract}
The life-history of Mazocraes alosae Hermann, 1782 on one of its hosts, the Pontic shad Alosa immaculata Bennett, is described for the first time. This anadromous fish, which occurs off the coast of the Crimea and migrates from the Black Sea to the Sea of Azov and into the River Don for spawning, was studied throughout its migration and during all seasons. It is demonstrated that the period of reproduction of this monogenean is significantly longer than that reported for the population in the Caspian Sea, lasting from April to November with a peak in April-May, and continues both in the sea and the river. Experiments showed that water salinity does not limit the development of the eggs or the hatching of the oncomiracidia. Our data reveal that the abundance of $M$. alosae is not determined by the size or sex of mature fish and that shad of less than two years old can also be infected with this monogenean, although less frequently than older fish. The direction of the migration of $A$. immaculata, either from the Black Sea to the Sea of Azov and into the rivers or in the opposite direction, does not influence the number of monogeneans present on the host. The main factor affecting the dynamics of the abundance of this monogenean is season, and, as has been indicated previously in the Caspian Sea basin, there is a synchronisation between the parasite's life-history and both the host's spawning behaviour and the duration of its migration.
\end{abstract}

Keywords: Fish parasite, infection indices, reproduction, season dynamics, influence of host and environment factors, Pontic shad, fish migration

The Pontic shad, Alosa immaculata Bennett, is an anadromous clupeid fish of significant economic value to all countries in the Black Sea region and also to those located along the large rivers of the Black Sea basin. Throughout recent decades, a decrease in the population of this fish throughout the region has been recorded, mainly as a result of overfishing, pollution and dam construction (Lenhardt 2016). Consequently, it has become important to study all factors which may affect fish stocks in the wild, and one of these is parasitism.

Mazocraes alosae Hermann, 1782 is a haematophagous, gill-dwelling monogenean, known to parasitise clupeid fishes in North-East Atlantic basin, as well as in the Caspian Sea. Blood-feeding monogeneans are often reported as causing significant harm to their hosts, either directly affecting the respiratory function of the host's gills or by facilitating infections of various opportunist pathogens, such as viruses, bacteria and fungi (Lia et al. 2007, Rubio-Godoy 2007).

In the Black (and Azov) Sea and its basin, in addition to A. immaculata, M. alosae is found on four other species of
Alosa, namely A. maeotica (Grimm), A. caspia (Eichwald), A. fallax (Lacépède) and A. tanaica (Grimm), and rarely on Clupeonella cultriventris (Nordmann) and Engraulis encrasicolus (Linnaeus). This monogenean has been recorded from the Black Sea close to the Caucasian coast of Russia (Pogorel'tseva 1952, Kamenev 1953, 1957) and off the Crimea (Pogorel'tseva 1952, Popyuk 2009), off the Ukrainian, Romanian and Bulgarian coasts (Chernishenko 1955, Roman 1956, Dimitrov 1989) and in the Dnieper, Dniester, Southern Bug and Danube River basins (Osmanov 1940, Petrushevsky 1957, Paskevichute 1971), off the coast of Turkey (Özer et al. 2013), in the Kerch Strait (Isaychikov 1925, Kamenev 1953, 1957, Popyuk 2011), in the Sea of Azov and the rivers flowing into it (Kamenev 1953, 1957, Solonchenko 1982), and in Lake Paleostomi, Georgia (Chernova 1975).

Most of the reports of M. alosae in the Black-Azov Sea region include data only on the infection rate in a single sample or summarised data for the entire study period. Only a very few studies compare the numbers of monogeneans in different seasons and regions, either taking 


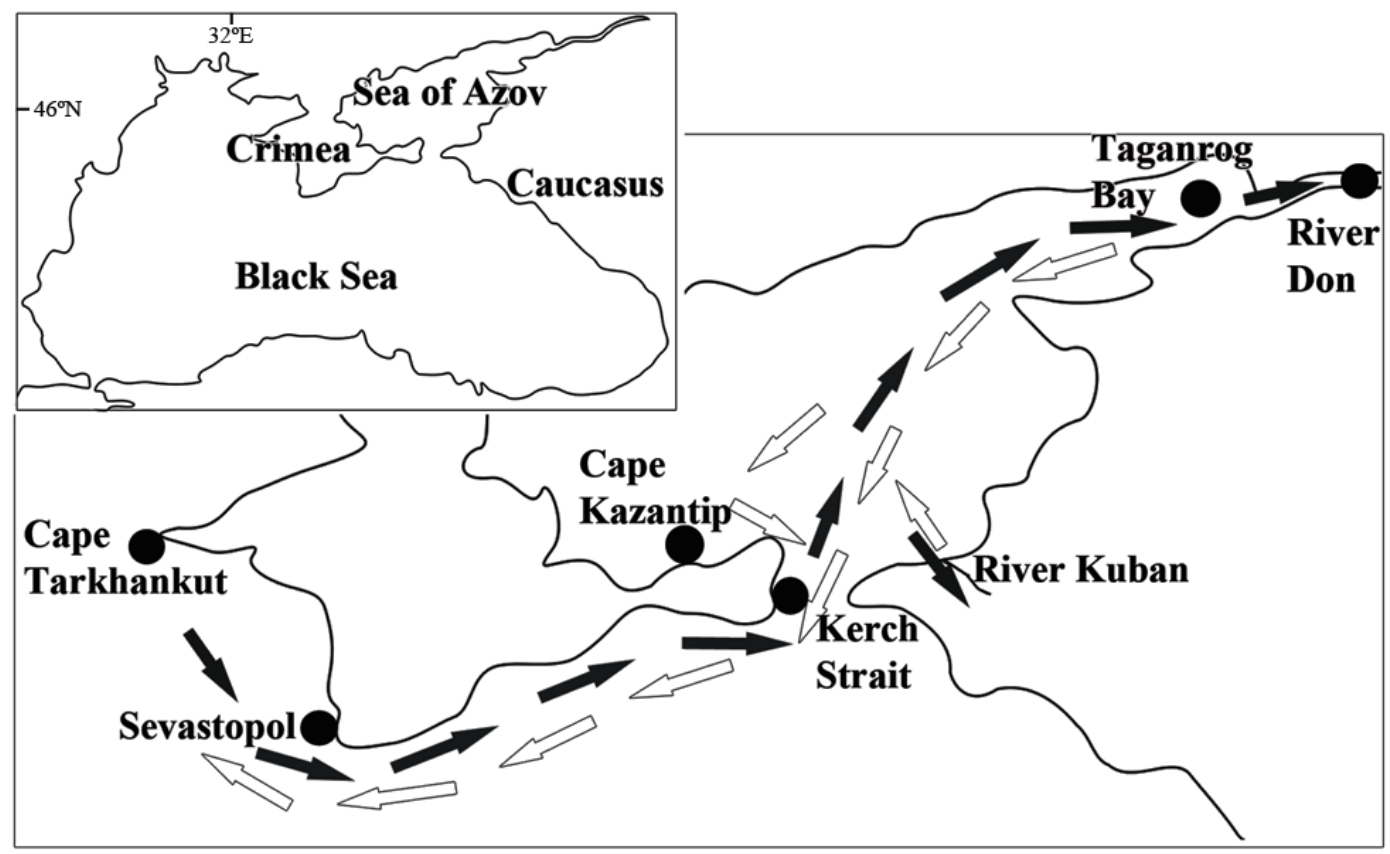

Fig. 1. Sampling sites $(\bullet)$ and a diagrammatic representation of the migration of Alosa immaculata Bennett along the southern coast of the Crimea and into the Don and Kuban Rivers: $(\rightarrow$ ) to the spawning sites between late February and about the middle of August; $\Leftrightarrow)$ return migration between the second half of July and December.

Table 1. Characteristics of the samples of Alosa immaculata Bennett and their infection with Mazocraes alosae Hermann, 1782 , grouped by months ${ }^{\dagger}$.

\begin{tabular}{|c|c|c|c|c|c|c|c|c|}
\hline Months & Year & Regions & $\begin{array}{l}\text { Number of } \\
\text { fishes }\end{array}$ & $\begin{array}{l}\text { Total length of fishes } \\
\text { min-max, cm (mean } \\
\pm \mathrm{SD})\end{array}$ & $\begin{array}{c}\text { Prevalence } \\
\%\end{array}$ & $\begin{array}{c}\text { Intensity of } \\
\text { infection } \\
\text { min-max } \\
\text { (mean)* }\end{array}$ & $\begin{array}{l}\text { Abundance } \\
\text { mean } \pm \mathrm{SD}\end{array}$ & $\begin{array}{c}\text { Length of } \\
\text { worms } \\
\text { mean SD }\left(\mathrm{N}^{+}\right)\end{array}$ \\
\hline \multirow{5}{*}{ II-III } & 2009 & Cape Tarkhankut, Black Sea & 15 & $12-21.5(16 \pm 4)$ & 0 & 0 & 0 & - \\
\hline & 2009 & \multirow{2}{*}{ off Sevastopol, Black Sea } & 21 & $11.5-28(17 \pm 4)$ & 57 & $1-4(1.75)$ & $1.0 \pm 1.2$ & - \\
\hline & 2020 & & 15 & $13.5-20(17.5 \pm 2)$ & 53 & $1-3(1.9)$ & $1.0 \pm 1.1$ & $8.4 \pm 1.2(15)$ \\
\hline & 2010 & \multirow{2}{*}{ Kerch Strait, B $\rightarrow \mathrm{A}^{\ddagger}$} & 16 & $11-30(20 \pm 8)$ & 19 & $3,6,7$ & $1.0 \pm 2.3$ & $7.5 \pm 1.7(13)$ \\
\hline & 2012 & & 19 & $13-27(23 \pm 3)$ & 37 & $1-7(3.0)$ & $1.1 \pm 1.85$ & $7.3 \pm 1.5(21)$ \\
\hline \multirow{6}{*}{$\mathrm{IV}-\mathrm{V}$} & 2009 & Cape Tarkhankut, Black Sea & 12 & $\begin{array}{c}12-12.5 \\
(12.3 \pm 0.2)\end{array}$ & 17 & 1,3 & $0.3 \pm 0.9$ & - \\
\hline & 2010 & \multirow{2}{*}{ Kerch Strait, B $\rightarrow$ A } & 27 & $16-39(23 \pm 6)$ & 74 & $1-28(4.29)$ & $3.2 \pm 5.4$ & $7.5 \pm 2.0(72)$ \\
\hline & 2012 & & 28 & $15.5-33(24 \pm 6)$ & 71 & $1-22(3.85)$ & $2.8 \pm 5.4$ & $6.8 \pm 2.1(71)$ \\
\hline & 2012 & off Sevastopol, Black Sea & 28 & $12-27(16 \pm 4)$ & 64 & $2-44(12)$ & $7.7 \pm 11.8$ & $3.6 \pm 2.0(162)$ \\
\hline & & Taganrog Bay, Sea of Azov & 10 & $24-30.5(27.5 \pm 2)$ & 100 & $6-78(19.3)$ & $19 \pm 21.6$ & $5.7 \pm 2.1(163)$ \\
\hline & 2016 & Lower reaches of River Don & 15 & $16-22.2(20 \pm 2)$ & 100 & $1-32(13.1)$ & $13 \pm 9.4$ & $4.5 \pm 2.1(180)$ \\
\hline \multirow{4}{*}{ VI } & 2010 & \multirow{2}{*}{ Kerch Strait, $\mathrm{B} \rightarrow \mathrm{A}$} & 17 & $15-23(17 \pm 3)$ & 53 & $1-7(3.1)$ & $1.6 \pm 2.1$ & $7.5 \pm 1.4(22)$ \\
\hline & 2012 & & 12 & $18-21(19 \pm 1)$ & 42 & $1-12(4.0)$ & $1.7 \pm 3.4$ & $7.3 \pm 1.7(15)$ \\
\hline & 2009 & off Sevastopol, Black Sea & 12 & $12-17.5(14.5 \pm 2)$ & 25 & $3,12,5$ & $1.7 \pm 3.6$ & - \\
\hline & 2012 & Taganrog Bay, Sea of Azov & 10 & $20.5-23.5(22 \pm 1)$ & 100 & $4-43(12.2)$ & $12 \pm 11.6$ & $5.8 \pm 1.6(116)$ \\
\hline \multirow{2}{*}{ VII } & 2010 & \multirow{2}{*}{ Kerch Strait, $\mathrm{A} \rightarrow \mathrm{B}$} & 19 & $12-18.5(17 \pm 2)$ & 47 & $1-73(27.2)$ & $13 \pm 21.7$ & $6.0 \pm 1.7(144)$ \\
\hline & 2012 & & 18 & $15-23.5(20.5 \pm 2)$ & 50 & $2-102(29.7)$ & $15 \pm 25.7$ & $6.2 \pm 1.3(167)$ \\
\hline IX & 2010 & Kerch Strait, $\mathrm{A} \rightarrow \mathrm{B}$ & 15 & $22-26.5(24 \pm 2)$ & 33 & $1-6(3.0)$ & $1.0 \pm 1.8$ & $5.3 \pm 2.2(12)$ \\
\hline \multirow{5}{*}{$\mathrm{X}-\mathrm{XI}$} & 2010 & \multirow{2}{*}{ Kerch Strait, $\mathrm{A} \rightarrow \mathrm{B}$} & 25 & $13-31.5(26.5 \pm 5)$ & 40 & $1-25(5.0)$ & $2.0 \pm 5.3$ & $6.6 \pm 1.8(43)$ \\
\hline & 2012 & & 30 & $18-28.5(25 \pm 2)$ & 55 & $1-18(4.9)$ & $2.6 \pm 3.9$ & $7.0 \pm 2.3(67)$ \\
\hline & 2011 & Cape Kazantip, Sea of Azov & 25 & $22-30.5(27 \pm 2)$ & 64 & $1-17(4.7)$ & $3.0 \pm 3.7$ & $5.7 \pm 1.7(45)$ \\
\hline & 2009 & & 12 & $13-18(16 \pm 2)$ & 0 & 0 & 0 & - \\
\hline & 2020 & Sevastopol, Black Sea & 20 & $14.5-26(20 \pm 3)$ & 55 & $1-11(3.7)$ & $2.1 \pm 2.8$ & $7.5 \pm 1.0(38)$ \\
\hline \multirow{3}{*}{ XII-I } & 2010 & Kerch Strait, $\mathrm{A} \rightarrow \mathrm{B}$ & 13 & $27.5-30.5(29 \pm 1)$ & 0 & 0 & 0 & - \\
\hline & 2009 & \multirow{2}{*}{ off Sevastopol, Black Sea } & 15 & $13.5-15.5(14.5 \pm 1)$ & 30 & 1 & $0.3 \pm 0.5$ & $8.7(5)$ \\
\hline & 2012 & & 14 & $11-22(16 \pm 3)$ & 7 & 1 & $0.1 \pm 0.3$ & - \\
\hline
\end{tabular}

${ }^{\dagger}$ The months are combined into one group (season), taking into account the fish and monogenean biology and whether the analysed infection and reproductive indices for these months are at the same level. Thus, fish migration and the appearance of the first ovigerous monogeneans (and consequently the birth of new worms) commence in about the second half of February and the first half of March; hence, the first natural period for an analysis of the life history of this monogenean is months II-III and the last months XII-I, thus completing the annual seasonal cycle.

* If the number of infected fish $>5$, in other cases the numbers of parasites per fish are separated by commas; ${ }^{+} \mathrm{N}-$ number of measured worms; ${ }^{*} \mathrm{~B}-$ Black Sea; $\rightarrow$ direction of fish migration through the Kerch Strait; A - Sea of Azov 


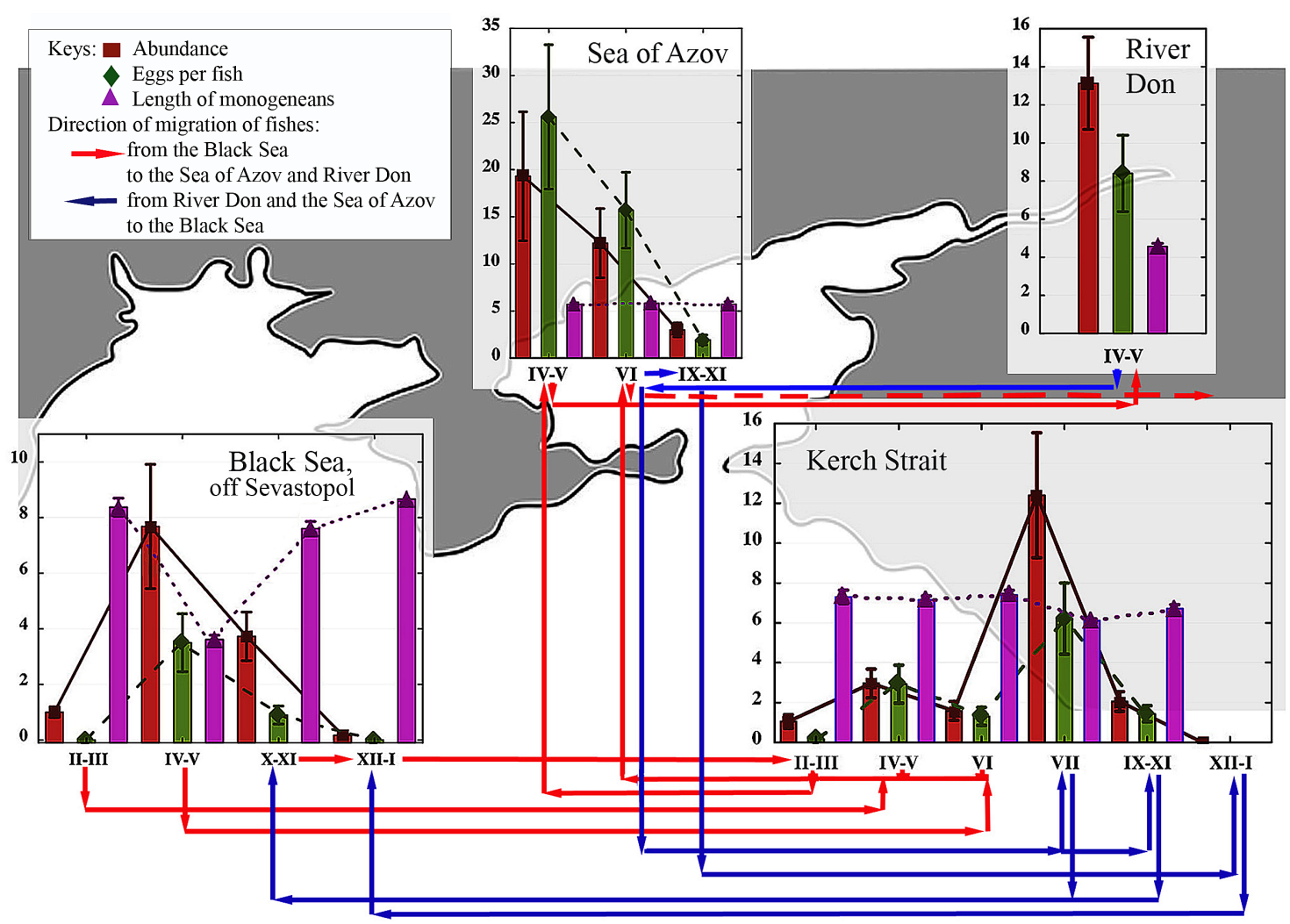

Fig. 2. Seasonal dynamics of the main infection parameters of the infrapopulations of Mazocraes alosae Hermann, 1782 in the Black and Azov Seas, the Kerch Strait and the River Don, and diagrammatic associations between these infrapopulations based on data from fish migration. $\mathrm{x}$ axis: I-XII months; $\mathrm{y}$ axis: Abundance, Number of eggs per fish and Length of monogeneans.

into account the spawning behaviour of the shad (Kamenev 1953, 1957, Petrushevsky 1957) or without such an analysis (Solonchenko 1982). Furthermore, there is no information on the actual specimens of $M$. alosae in terms of their size and the presence of eggs, with the result that there are few data on the life-history of this parasite in the region. Hence, there are no answers to questions on the reproductive period of $M$. alosae in the Black Sea basin, the peculiarities of the synchronisation of its life-cycle with the migration behaviour of its hosts or the likelihood of monogenean reproduction in fresh or marine waters, or both.

Previous descriptions of the life-history of M. alosae were given for specimens parasitising Alosa spp. in the Caspian Sea by Bychowsky (1957) and A. fallax in the Bristol Channel (Celtic Sea) and neighbouring River Severn, UK by Aprahamian (1985). The effects of the size, sex and migration into the rivers of Alosa spp. on the infection indices of this monogenean have also been analysed in a small number of studies (Bao et al. 2015, Gérard et al. 2016, 2017), but there are no data on the influence of salinity on the parasite's reproduction.

These and other aspects of the life-history of M. alosae were investigated for a population parasitising the Pontic shad A. immaculata, which occurs in the north-eastern part of the Black Sea off the coast of the Crimea and migrates into the Sea of Azov and the Rivers Don and Kuban.

\section{MATERIALS AND METHODS}

\section{Collecting and examination}

Fish were caught in the Kerch Strait (45.13N, 34.42E) throughout all seasons during 2010 and 2012; the Sea of Azov close to Cape Kazantip (45.47N, 35.83E) during autumn 2011; Taganrog Bay (47.07N, 39.25E) during summer 2012 and spring 2016; the River Don, c. $60 \mathrm{~km}$ from its mouth $(47.18 \mathrm{~N}, 39.65 \mathrm{E})$ during spring 2016; and the Black Sea off Sevastopol (44.60N, 33.43E) during all seasons 2009, winter and spring 2012 and spring and autumn 2020, and off Cape Tarkhankut (45.33N, 32.47E) during winter and spring 2009 (Fig. 1).

The salinity in the study areas is as follows: $17-18 \%$ off Sevastopol and Cape Tarkhankut, $14-17 \%$ in the Kerch Strait and Sea of Azov, 13-14\%o near Cape Kazantip, 5-12\%o in Taganrog Bay, and $0-0.6 \%$ in the lower reaches of the River Don (Korshenko 2017).

A total of 463 specimens of Alosa immaculata were examined fresh (Table 1). The total length and the sex of the fish were recorded, and the gills were removed and studied under a dissecting microscope for the presence of monogeneans. Only specimens of Mazocraes alosae were found. All of the parasites were collected live and mounted, under a slight coverslip pressure, in glycerine-jelly (prepared with $0.5 \mathrm{~g}$ carbolic acid) after Gusev (1983). Body length and the number and level of development of the eggs were determined for 1,363 monogeneans in total, using an Olympus CX41 microscope fitted with phase-contrast optics, a CMOS SC50 camera and Olympus cellSens software. 
Table 3. Kolmogorov-Smirnov test for comparisons of the abundance of Mazocraes alosae Hermann, 1782 parasitising Alosa immaculata Bennett in the Kerch Strait in different seasons for the years 2010 and 2012.

\begin{tabular}{|c|c|c|c|c|c|c|c|c|c|}
\hline \multirow[t]{2}{*}{ Months } & \multicolumn{2}{|c|}{ Abundance } & \multicolumn{2}{|c|}{ Standard deviation } & \multicolumn{2}{|c|}{ Number } & $\begin{array}{c}\text { Max negative } \\
\text { difference }\end{array}$ & $\begin{array}{c}\text { Max positive } \\
\text { difference }\end{array}$ & p-value \\
\hline & 2010 & 2012 & 2010 & 2012 & 2010 & 2012 & & 2010 vs 2012 & \\
\hline II-III & 1.00 & 1.11 & 2.28 & 1.85 & 16 & 19 & -0.181 & 0.072 & $>0.10$ \\
\hline IV-V & 3.19 & 2.75 & 5.41 & 5.39 & 27 & 28 & -0.034 & 0.229 & $>0.10$ \\
\hline VI & 1.65 & 1.67 & 2.09 & 3.42 & 17 & 12 & -0.083 & 0.137 & $>0.10$ \\
\hline VII & 12.89 & 14.83 & 21.65 & 25.66 & 19 & 18 & -0.1329 & 0.155 & $>0.10$ \\
\hline $\mathrm{X}-\mathrm{XI}$ & 2.00 & 2.63 & 5.315 & 3.88 & 25 & 30 & -0.260 & 0.047 & $>0.10$ \\
\hline
\end{tabular}

Table 2. Characteristics of the distribution of the specimens of Mazocraes alosae Hermann, 1782 among samples of Alosa immaculata Bennett.

\begin{tabular}{lccccc}
\hline Regions & Months & Year & $\begin{array}{c}\text { Fish with } \\
\leq 5 \text { worms, } \\
\%^{\dagger}\end{array}$ & $\begin{array}{c}\text { Shapiro- } \\
\text { Wilk test }\end{array}$ & p-value \\
\hline off Sevastopol & II-III & 2009 & 100 & 0.80 & 0.0001 \\
& IV-V & 2012 & 55 & 0.67 & 0.0001 \\
& IV-V & 2010 & 75 & 0.54 & 0.0001 \\
Kerch Strait & 2012 & 89 & 0.46 & 0.0001 \\
& X-XI & 2010 & 80 & 0.42 & 0.0001 \\
Cape Kazantip & X-XI & 2012 & 75 & 0.71 & 0.0001 \\
Taganrog Bay & IV & 2011 & 69 & 0.72 & 0.0001 \\
River Don & VI & 2012 & 0 & 0.62 & 0.0001 \\
\multicolumn{7}{l}{$\%$ IV-V of total number of fishes in the sample } & 2016 & 20 & 0.68 & 0.001 \\
\end{tabular}

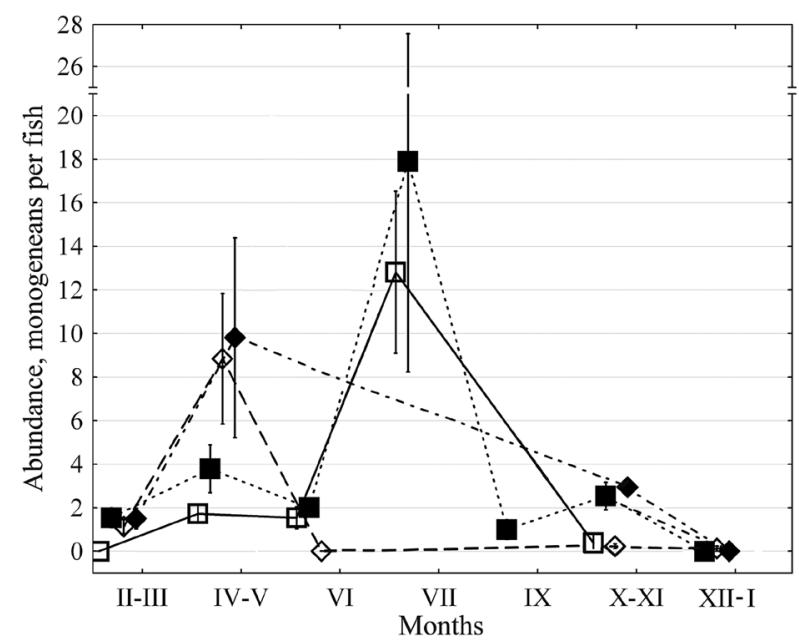

In order to study the relationship between the infection and host size, the fish were divided into three groups on the basis of total length and basic biological data (Svetovidov 1964): Group 1 - length $11-12.5 \mathrm{~cm}$, unspawned fish with ages of less than 2 years; Group 2- length 13-20 cm, ages 2-3+ years, most of these fish spawn for the first time; and Group 3 - length 20.5-39 cm, ages $4-5+$ years, most of these fish have spawned more than once.

\section{Statistical analyses}

The level of parasitic infection is characterised by the prevalence (number of infected hosts/number of examined hosts, as a percentage), intensity (total number of parasites/number of infected hosts) and abundance (total number of parasites/number of examined hosts). The mean, standard deviation and range are used to describe infection intensity; abundance is presented in graphs as the mean and standard error. To check the frequency distribution of the infection intensity, the Shapiro-Wilk test was used for samples where the number of infected fishes was not less than 10 .

The significance of the influence of season, region and fish size groups on the abundance of $M$. alosae, and the relationship of the first two factors on monogenean size, was described by the Kruskal-Wallis test (one-way nonparametric ANOVA for multiple comparison), and, if the $\mathrm{H}_{0}$ hypothesis was rejected, we used multiple comparisons of mean rank for all groups (non-parametric ANOVA post-hoc test). Differences in the abundance of monogeneans between different years, host size or host sex groups were determined using the Kolmogorov-Smirnov two sample test. The Pearson correlation estimated for the log-transformed prevalence and intensity of infection, and the Spearman correlation was calculated for analysing the relationship between the abundance of M. alosae and the total length of the host but only for infected fish. For all tests, significance was accepted at $p<0.05$. Statisti-

Fig. 3. Seasonal dynamics of the abundance (mean $\pm \mathrm{SE}$ ) of $\mathrm{Ma}$ zocraes alosae Hermann, 1782 parasitising Pontic shad Alosa immaculata Bennett of the different total length groups: Kerch Strait - Group 2 (口); Kerch Strait - Group 3 (ם); Sevastopol - Group 2 $(\diamond)$; Sevastopol - Group $3(\bullet)$

cal analyses were carried out using the Statistica 6 for Windows software package.

\section{Laboratory experiment}

The effect of salinity on the embryonation period and hatching success of eggs of $M$. alosae was examined in the laboratory in vitro. Gravid monogeneans, collected from the gills of $A$. immaculata during May in the marine biotope off Sevastopol, were immersed in Petri dishes containing 18\%o seawater. To stimulate egg-laying, the temperature shock method was used: for $30 \mathrm{~min}$ monogeneans were kept at a temperature of $5{ }^{\circ} \mathrm{C}$ and then placed in temperature conditions of $18^{\circ} \mathrm{C}$; as a result, intensive egg-laying began. An ambient temperature of $17{ }^{\circ} \mathrm{C}$ was maintained throughout the experiment.

Only eggs with two fully-developed filaments were selected for the experiment. In the first experiment, five eggs were placed in each Petri dish with three different water salinities, 18\%o, 9\%o and freshwater; this was replicated (Table 1) three times. In another experiment, four eggs were placed in water with salinities of $18 \%, 9 \%$ and $1.8 \%$, also replicated three times, but with the addition of a $2 \%$ solution of streptomycin and benzylpenicillin in each container. The water at different salinities was obtained by using seawater from the Black Sea $(18 \%)$ by dilution with freshwater. The water was filtered and sterilised with UV and the salinity measured using an H196822 seawater refractometer. Each day, eggs were transferred to a new container with the same water conditions. 
Table 4. P-values of nonparametric ANOVA post-hoc test in terms of the abundance of Mazocraes alosae Hermann, 1782 parasitising Alosa immaculata Bennett in different seasons and regions.

\begin{tabular}{|c|c|c|c|c|c|c|c|c|c|c|c|c|c|c|c|c|}
\hline & & \multicolumn{2}{|c|}{$\mathrm{II}^{-\mathrm{III}^{\dagger}}$} & \multicolumn{5}{|c|}{ IV-V } & \multicolumn{3}{|c|}{ VI } & \multirow{2}{*}{$\begin{array}{l}\text { VII } \\
\text { KS }\end{array}$} & \multirow{2}{*}{$\begin{array}{l}\text { IX } \\
\text { KS }\end{array}$} & \multicolumn{3}{|c|}{$\mathrm{X}-\mathrm{XI}$} \\
\hline & & $\mathrm{KS}^{\ddagger}$ & $\mathrm{S}$ & KS & $\mathrm{S}$ & $\mathrm{T}$ & TB & $\mathrm{RD}$ & KS & $\mathrm{S}$ & TB & & & KS & $\mathrm{K}$ & $\mathrm{S}$ \\
\hline \multirow[t]{3}{*}{$\overline{\mathrm{II}}-\mathrm{III}{ }^{\dagger}$} & $\mathrm{S}^{\ddagger}$ & 1.00 & & & & & & & & & & & & & & \\
\hline & KS & 0.69 & 1.00 & & & & & & & & & & & & & \\
\hline & $\mathrm{S}$ & 0.17 & 1.00 & 1.00 & & & & & & & & & & & & \\
\hline \multirow[t]{4}{*}{ IV-V } & $\mathrm{T}$ & 1.00 & 1.00 & 0.93 & 0.26 & & & & & & & & & & & \\
\hline & TB & $<0.01$ & $<0.01$ & 0.04 & 0.71 & $<0.01$ & & & & & & & & & & \\
\hline & $\mathrm{RD}$ & $<0.01$ & $<0.01$ & 0.03 & 0.86 & $<0.01$ & 1.00 & & & & & & & & & \\
\hline & KS & 1.00 & 1.00 & 1.00 & 1.00 & 1.00 & $<0.01$ & $<0.01$ & & & & & & & & \\
\hline \multirow[t]{2}{*}{ VI } & $\mathrm{S}$ & 1.00 & 1.00 & 1.00 & 1.00 & 1.00 & $<0.01$ & $<0.01$ & 1.00 & & & & & & & \\
\hline & TB & $<0.01$ & 0.02 & 0.17 & 1.00 & $<0.01$ & 1.00 & 1.00 & 0.01 & 0.01 & & & & & & \\
\hline VII & KS & 0.03 & 0.04 & 1.00 & 1.00 & $<0.01$ & 0.07 & 0.06 & 0.04 & 0.04 & 0.26 & & & & & \\
\hline \multirow[t]{2}{*}{ IX } & KS & 1.00 & 1.00 & 1.00 & 1.00 & 1.00 & $<\mathbf{0 . 0 0 1}$ & $<0.01$ & 1.00 & 1.00 & $<0.01$ & 1.00 & & & & \\
\hline & KS & 1.00 & 1.00 & 1.00 & 1.00 & 1.00 & $<0.001$ & $<0.01$ & 1.00 & 1.00 & $<0.01$ & 1.00 & 1.00 & & & \\
\hline \multirow[t]{2}{*}{$\mathrm{X}-\mathrm{XI}$} & К & 1.00 & 1.00 & 1.00 & 1.00 & 1.00 & 0.04 & 0.04 & 1.00 & 1.00 & 0.02 & 1.00 & 1.00 & 1.00 & & \\
\hline & S & 1.00 & 1.00 & 1.00 & 0.61 & 1.00 & $<0.001$ & $<0.01$ & 1.00 & 1.00 & $<0.01$ & 1.00 & 1.00 & 1.00 & 1.00 & \\
\hline XII-I & $\mathrm{S}$ & 1.00 & 1.00 & 0.04 & 0.03 & 1.00 & $<0.001$ & $<0.01$ & 1.00 & 1.00 & $<0.01$ & 0.04 & 1.00 & 1.00 & 0.24 & 1.00 \\
\hline
\end{tabular}

\section{RESULTS}

\section{Characteristics of the infection level and distribution model}

Prevalence varied significantly from 7 to $100 \%$, but, in general, almost half (48\%) of the Pontic shad examined were free from infection with Mazocraes alosae, and a third of the infected fishes $(17 \%$ of the total number examined) harboured only 1-2 monogeneans. The maximum level of intensity was 102, with a mean value of 29.7 (Table 1). There was no significant correlation between prevalence and intensity $\left(r^{2}=0.48, p=0.10\right)$.

The distribution of monogeneans among the infected shad does not correspond with an assumption of normality in nine of the ten samples analysed, and the number of fish with a low intensity of infection $(\leq 5)$ is greater than the number of heavily infected hosts (Table 2). An exception was the sample investigated from the River Don, in which $100 \%$ prevalence was recorded and $66 \%$ of the fish were infected with more than ten parasites.

\section{Inter-year variability in the infection level}

No inter-year variability (2010 vs 2012) was found in the abundance of M. alosae infecting Alosa immaculata in the Kerch Strait during the same months (compared for five seasons - Table 3). Moreover, the level of infection observed during October-November of 2011 in Pontic shad near Cape Kazantip corresponded with that recorded in the Kerch Strait during these months for 2010 and 2012 (Table 1). This is worthy of mention, because fish caught near Kazantip, in the pre-strait zone of the Sea of Azov (Fig. 1), belong to the same part of the population of A. immacula$t a$ which migrate through the Kerch strait during the same period.

The season dynamics of the number of monogeneans parasitising Pontic shad investigated near Sevastopol in different years (2009 vs 2012 vs 2020) had the same trend, namely infection indices were higher in the spring than in the autumn-winter (Table 1). However, the fish examined in April-May of 2012 were more heavily infected than in the previous and following months in 2009 and 2020, but a similar, albeit less pronounced, spring peak in April-May was also observed in the Kerch Strait during 2010 and 2012 (Table 1).

Thus, no significant differences between years in the seasonal dynamics of the abundance of monogeneans in the Kerch Strait (Table 3) and in the Black Sea off Crimea were observed.

\section{Effect of season, region, salinity and fish migration on the infection level}

According to the migratory behaviour of $A$. immaculata (see Svetovidov 1964, Froese and Pauly 2019), shad occur throughout the year only in the Kerch Strait. In the Sea of Azov and rivers, fish are abundant from spring to early summer, and in the Black Sea off the Crimean coast they are common from October to early June. Therefore, it is possible to compare samples from all seasons only for the Kerch Strait and partly for Crimean coastal waters. Similarly, data for all of the compared regions are available only during the spring-summer period.

Consequently, season significantly affected the abundance of M. alosae infected fish in the Kerch Strait (Kruskal-Wallis test: $\mathrm{H}_{(\mathrm{df}=5, \mathrm{n}=226}=13.8, \mathrm{p}=0.016$ ) and in the Black Sea close to Sevastopol $\left(\mathrm{H}_{(\mathrm{df}=4, \mathrm{n}=137)}=24.7, \mathrm{p}<\right.$ $0.001)$.

During the autumn and winter months, when the number of monogeneans is low in both the Kerch Strait and the Black Sea, there are no significant differences between these regions in terms of the infection indices (Table 1, Fig. 2). However, region significantly affected the abundance of M. alosae during April-May (Kruskal-Wallis test: $\mathrm{H}_{\text {(df- } 4 \text {, }}$ $\mathrm{n}=120)=46.4, \mathrm{p}<0.001)$ and June: $\mathrm{H}_{(\mathrm{df}=2, \mathrm{n}=51)}=21.7, \mathrm{p}<$ $0.001)$

However, for the same monogenean infrapopulations parasitising anadromous fish such as $A$. immaculata, the region also changes depending on season. So, both factors acting together significantly influence the abundance of $M$. alosae (Kruskal-Wallis test: $\mathrm{H}_{(\mathrm{df}=16, \mathrm{n}=435)}=120, \mathrm{p}<0.001$ ). 
Table 5. Infection indices of Mazocraes alosae Hermann, 1782 parasitising Alosa immaculata Bennett for groups of different size and sex.

\begin{tabular}{|c|c|c|c|c|}
\hline Size groups of fish, min-max of total length $(\mathrm{cm})$, sex & Number of fish & Prevalence, $\%$ & $\begin{array}{l}\text { Intensity of infection } \\
\text { min-max }(\text { mean } \pm \text { SD) }\end{array}$ & $\begin{array}{l}\text { Abundance } \\
\text { mean } \pm \mathrm{SD}\end{array}$ \\
\hline Group $1,11-12.5$, both sexes & 46 & 15 & $1-4(2.4 \pm 1.1)$ & $0.4 \pm 1.0$ \\
\hline Group 2, 13-20, both sexes & 195 & 46 & $1-73(9.3 \pm 13.2)$ & $4.3 \pm 10.1$ \\
\hline Group 2, 13-20, ${ }^{\pi}$ & 78 & 55 & $1-73(17.1 \pm 21.4)$ & $9.4 \pm 18.0$ \\
\hline Group 2, 14-20, & 117 & 40 & $1-41(8.4 \pm 12.0)$ & $3.4 \pm 8.7$ \\
\hline Group 3, 20.5-39, both sexes & 222 & 57 & $1-102(7.6 \pm 13.0)$ & $4.3 \pm 10.5$ \\
\hline Group 3, 20.5-31, ठ & 72 & 50 & $1-32(7.1 \pm 8.5)$ & $4.1 \pm 7.3$ \\
\hline Group 3, 20.5-39, 운 & 150 & 61 & $1-102(5.8 \pm 13.4)$ & $3.5 \pm 10.0$ \\
\hline
\end{tabular}

The abundance of these monogeneans is significantly greater on Pontic shad from Taganrog Bay and the River Don during May and June than on all of the other populations investigated (Fig. 2; Table 4). However, there was no significant difference in the monogenean infection indices recorded from marine, pre-spawning fish examined from the bay and those of shad caught in the river (Tables 1, 4).

Pontic shad that pass from the Black Sea to the Sea of Azov during this period (April-June) through the Kerch Strait are only lightly infected by M. alosae. Similar low values of abundance were observed at the beginning of shad migration in the same direction during FebruaryMarch (Fig. 2).

In late July, when the shad begin to return to the Black Sea through the Kerch Strait, their infection with monogeneans increases by more than sevenfold compared with the previous months. However, the abundance of M. alosae in shad examined in the strait during September was very low and remained at the same level throughout OctoberNovember, and fish passing through the strait to the Black Sea in December were free of the parasite (Fig. 2).

In the Black Sea, both off the Sevastopol region and close to Tarkhankut, the abundance of M. alosae was relatively low during almost all seasons, reaching its maximum in spring. Consequently, a pronounced seasonal dynamic in the abundance of $M$. alosae was revealed for most study regions (Fig. 2). At the same time, there was no dependence of the monogenean infection indices on the direction of host migration through the Kerch Strait or on the salinity of the water. The abundance of M. alosae is at about the same level between February and June, when the fish pass from the Black Sea to the Sea of Azov, and between August and November, when the shad migrate in the opposite direction. Only during July were fish heavily infected with M. alosae caught in the Kerch Strait, when the parasite's abundance corresponded to that observed during May and June in Taganrog Bay and the River Don (Fig. 2), despite significant differences in the salinity between these areas.

\section{Effect of fish size (total length) and sex on the infection level}

The level of infection with M. alosae generally depends on the host size group (Kruskal-Wallis test: $\mathrm{H}_{(\mathrm{df}=2, \mathrm{n}=463)}=$ 27.3, $\mathrm{p}<0.001)$. Small shad of Group 1 had significantly lower levels of infection than fish from the other two groups (Table 5). However, no significant differences were found between the abundance of the parasites in larger fish of Groups 2 and 3 (Kolmogorov-Smirnov Test ${ }_{(\mathrm{df}=2, \mathrm{n}=417)} \mathrm{p}$ $>0.1$ ).

Taking into account the variation in the size composition of the samples of Pontic shad investigated in the different seasons (Table 1), the abundance of M. alosae parasitising fishes of Groups 2 and 3 in the Kerch Strait and off Sevastopol was analysed separately, but no marked differences in the seasonal dynamics of the infection levels of these groups were found (Fig. 3).

In general, no positive relationship between the infection of M. alosae and the size of A. immaculata was observed (Spearman rank $\mathrm{R}=0.018, \mathrm{p}=0.8$ ). So, the largest shad passing from the Sea of Azov into the Black Sea in December are uninfected, but shad going in this same direction during July, represented mainly by Group 2 fish, are heavily infected with monogeneans (Figs. 2, 3). Thus, the different abundance of M. alosae in Pontic shad migrating during different seasons through the Kerch Strait is unrelated to differences in the size-age composition of these fish.

No effect of host sex on the abundance of M. alosae was revealed when testing all of the fish (Kolmogorov-Smirnov Test $\left._{(\mathrm{df}=1, \mathrm{n}=438)} ; \mathrm{p}>0.05\right)$. Monogeneans were found only on males in Group 1 shad, but the level of infection was very low (Table 5). However, no significant differences were found in monogenean abundance between males and females in the other two size groups (Kolmogorov-Smirnov Test for Group $2_{\text {(df }=1, \mathrm{n}=195)} ; \mathrm{p}>0.05$ and for Group $3_{\text {(df }=1 \text {, }}$ $\mathrm{n}=222) ; \mathrm{p}>0.10$ ). The same was true when comparing fish of the same sex but from different size groups (Kolmogorov-Smirnov Test between Groups 2 and 3 for males ${ }_{(\mathrm{d}=1,}$,

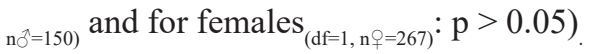

\section{Effect of season, region, salinity, and fish migration on monogenean egg production}

Egg-bearing specimens of M. alosae were found practically throughout the entire year, with the exception of December and January. In February and March, less than a third of the monogeneans have eggs in their uterus. Shad migrating through the Kerch Strait in April-May already have 10 times more worms with eggs, and $c .12$ ovigerous monogeneans had already been counted in each pre-spawning fish from Taganrog Bay in May. Those specimens of $A$. immaculata that had already entered the river by this time had only half of the number of ovigerous monogeneans and only one-third of the number of parasite eggs on each fish. During June, these characteristics of monogenean reproduction in the pre-spawning schools of shad in Taganrog 
Table 6. Presence of ovigerous specimens and number of eggs in Mazocraes alosae Hermann, 1782 parasitising Alosa immaculata Bennett migrating though the Kerch Strait, in the Sea of Azov and in the River Don during different months.

\begin{tabular}{|c|c|c|c|c|c|c|}
\hline \multirow[b]{2}{*}{ Months } & \multirow{2}{*}{$\begin{array}{l}\text { Region and direction } \\
\text { of fish migration }\end{array}$} & \multicolumn{2}{|c|}{ Worms with eggs, mean $\pm \mathrm{SE}$} & \multicolumn{3}{|c|}{ Number of eggs, mean \pm SE } \\
\hline & & Per fish & $\begin{array}{l}\text { Proportion of } \\
\text { all worms, \% }\end{array}$ & Per worm & Per infected fish & Per fish \\
\hline \multirow{2}{*}{ II-III } & Off Sevastopol, Black Sea & 0 & & 0 & & \\
\hline & Kerch Strait, $\mathrm{B} \rightarrow \mathrm{A}^{\dagger}$ & $0.2 \pm 0.1$ & $29 \pm 13$ & $0.3 \pm 0.2$ & $0.7 \pm 0.3$ & $0.2 \pm 0.1$ \\
\hline \multirow{4}{*}{ IV-V } & Off Sevastopol, Black Sea & $3.0 \pm 0.9$ & $41 \pm 2.7$ & $0.4 \pm 0.04$ & $5.4 \pm 1.4$ & $3.5 \pm 1.0$ \\
\hline & Kerch Strait, B $\rightarrow$ A & $1.7 \pm 0.5$ & $42 \pm 6$ & $0.7 \pm 0.1$ & $4.1 \pm 1.3$ & $2.9 \pm 0.9$ \\
\hline & Taganrog Bay & $11.8 \pm 3.8$ & $61 \pm 6$ & $1.4 \pm 0.2$ & $25.6 \pm 7.7$ & $25.6 \pm 7.7$ \\
\hline & River Don & $5.8 \pm 1.4$ & $45 \pm 3$ & $0.8 \pm 0.2$ & $8.4 \pm 2.0$ & $8.4 \pm 2.0$ \\
\hline \multirow{2}{*}{ VI } & Kerch Strait, B $\rightarrow$ A & $0.8 \pm 0.2$ & $56 \pm 11$ & $0.9 \pm 0.2$ & $2.7 \pm 0.8$ & $1.3 \pm 0.4$ \\
\hline & Taganrog Bay & $8.6 \pm 2.1$ & $76 \pm 8$ & $1.5 \pm 0.3$ & $16 \pm 4.2$ & $16 \pm 4.2$ \\
\hline VII & Kerch Strait, $\mathrm{A} \rightarrow \mathrm{B}$ & $4.5 \pm 1.3$ & $32 \pm 6$ & $0.5 \pm 0.1$ & $11.5 \pm 2.8$ & $6.2 \pm 1.8$ \\
\hline \multirow[t]{2}{*}{ IX } & Kerch Strait, $\mathrm{A} \rightarrow \mathrm{B}$ & $0.4 \pm 0.2$ & $52 \pm 13$ & $0.8 \pm 0.1$ & $1.4 \pm 0.4$ & $0.5 \pm 0.2$ \\
\hline & Off Sevastopol, Black Sea & $0.7 \pm 0.2$ & $34 \pm 8$ & $0.4 \pm 0.1$ & $1.6 \pm 0.5$ & $0.9 \pm 0.3$ \\
\hline \multirow[t]{2}{*}{$\mathrm{X}-\mathrm{XI}$} & Kerch Strait, $\mathrm{A} \rightarrow \mathrm{B}$ & $1.2 \pm 0.4$ & $40 \pm 7$ & $0.7 \pm 0.2$ & $3.0 \pm 0.7$ & $1.7 \pm 0.5$ \\
\hline & Cape Kazantip & $1.1 \pm 0.3$ & $41 \pm 7$ & $0.7 \pm 0.2$ & $3.2 \pm 0.7$ & $1.9 \pm 0.5$ \\
\hline \multirow{2}{*}{ XII-I } & Off Sevastopol, Black Sea & 0 & & 0 & & \\
\hline & Kerch Strait, $\mathrm{A} \rightarrow \mathrm{B}$ & 0 & & 0 & & \\
\hline
\end{tabular}

${ }^{\dagger} \mathrm{B}-$ Black Sea; $\rightarrow$ direction of fish migration; A - Sea of Azov

Bay were also greater than in the river. Thus, the number of ovigerous parasites decreases when the fish pass into freshwater. However, this number remains rather high in shad starting to return from the Sea of Azov to the Black Sea in late July, as one-third of the monogeneans were ovigerous and the number of eggs per fish remained quite high. Specimens of $A$. immaculata passing through the strait into the Black Sea in October-November still harboured egg-bearing worms (Table 6).

The average number of fully-developed eggs observed in the uterus of specimens of $M$. alosae did not exceed 2 (Table 6), but a maximum of 6-7 eggs at different developmental stages were observed in several individuals. The ratio between the number of monogenean eggs observed per examined fish and the abundance of $M$. alosae characterises the reproduction potential of the infrapopulation of this parasite. In fact, the average number of eggs per fish slightly exceeds monogenean abundance only in the pre-spawning schools of shad from Taganrog Bay during May and June (Fig. 2). The opposite result was found for monogeneans infecting fish in the river, and an even lower ratio was found in shad migrating through the Kerch Strait to the Black Sea during July. Such variation in this ratio, as the number of eggs decreases and the number of parasite increases, is logical during the period of intensive reproduction of this monogenean. In other seasons (from September to March) both indices, the number of eggs per fish and abundance, are relatively low and at the same level.

\section{Effect of season, region, salinity and fish migration on monogenean size}

Season and host habitat significantly affect the size (body length) of specimens of $M$. alosae, both when the data are combined (Kruskal-Wallis test: $\mathrm{H}_{(\mathrm{df}=12, \mathrm{n}=1363)}=$ $380, \mathrm{p}<0.001)$ and when they are examined separately (Kruskal-Wallis tests for seasons: $\mathrm{H}_{(\mathrm{df}=5, \mathrm{n}=1363)}=139, \mathrm{p}<$ 0.001; and for regions: $\left.\mathrm{H}_{(\mathrm{df}=4, \mathrm{n}=1363)}=190, \mathrm{p}<0.001\right)$.

The greatest average size of this monogenean was recorded off Sevastopol (Black Sea) during January-March and in the Kerch Strait throughout the period (February-
June) when the shad were migrating from the Black Sea to the Sea of Azov (Table 1, Fig. 2). In fact, parasites in pre-spawning shad from Taganrog Bay were, on average, only two-thirds of this size, as were specimens on spawning fish from the river during May-June and on spent fish returning to the Black Sea between late July and September. Obviously, there were many young specimens of $M$. alosae present in these samples. Monogeneans, which were collected later, during October-November, from shad migrating through the Kerch Strait, are already greater in average size.

\section{Experiments on the effect of salinity on the development and hatching of monogenean eggs}

In the first experiment, a single larva hatched in both $18 \%$ and $9 \%$ seawater after 7 days. At the same time (Day 7), 6-8 eggs containing motile larvae with eye-spots were observed in all salinities. Over 8 days, about $30 \%$ of eggs developed and 3-6 larvae hatched at all salinity values (Table 7). However, due to the fouling of eggs in $9 \%$ o seawater and freshwater, the experiment was stopped at this stage.

In the second experiment, the development within the eggs of an oncomiracidium with eye-spots was observed in all Petri dishes after 5 days. The first larvae hatched at all salinity values a day later. Thus, after 10 days, in total, $12-15$ oncomiracidia hatched in salinities of both $18 \%$ and $9 \%$ and 9 in 1.8.\% seawater, and more than half of the remaining eggs at each salinity were at the developmental stage when a motile larva with visible eye-spots was observed (Table 7).

Newly hatched larvae, first observed in the morning, were still actively moving after about 3 hours but immobile after 8 hours.

\section{DISCUSSION}

On the basis of the results presented above, the reproduction of Mazocraes alosae in the Black and Azov Sea region occurs from April to July, i.e. throughout the period when their host, Alosa immaculata, accumulates in schools and undertakes a spawning migration to and from freshwa- 
Table 7. Results of experiments on the development and hatching of eggs of Mazocraes alosae Hermann, 1782 in water of different salinity.

\begin{tabular}{|c|c|c|c|c|c|c|c|}
\hline \multirow{4}{*}{ Salinity, \%o } & \multirow{4}{*}{ Days of experiment } & \multicolumn{6}{|c|}{ Number of experiment set } \\
\hline & & First & Second & First & Second & First & Second \\
\hline & & \multirow{2}{*}{\multicolumn{2}{|c|}{ Unhatched eggs }} & Eggs contain & vith eye-s & \multirow{2}{*}{\multicolumn{2}{|c|}{ Hatched eggs }} \\
\hline & & & & ber / Proportion & 1 number & & \\
\hline \multirow{3}{*}{0} & 1 & 45 & - & 0 & - & 0 & - \\
\hline & 7 & 45 & - & 6 & - & 0 & - \\
\hline & $8^{+}$ & $42 / 93$ & - & $11 / 26$ & - & $3 \ddagger / 7$ & - \\
\hline \multirow{5}{*}{1.8} & 1 & - & 36 & - & 0 & - & 0 \\
\hline & 5 & - & 36 & - & 18 & - & 0 \\
\hline & 6 & - & 33 & - & 25 & - & 3 \\
\hline & 8 & - & 30 & - & 22 & - & 6 \\
\hline & 9 & - & $27 / 75$ & - & $22 / 61$ & - & $9 / 25$ \\
\hline \multirow{7}{*}{9} & 1 & 45 & 36 & 0 & 0 & 0 & 0 \\
\hline & 5 & 45 & 36 & 0 & 9 & 0 & 0 \\
\hline & 6 & 45 & 33 & 0 & 18 & 0 & 3 \\
\hline & 7 & 42 & 33 & 8 & 18 & 3 & 3 \\
\hline & 8 & $39 / 87$ & 33 & $15 / 33$ & 18 & $6 / 13$ & 3 \\
\hline & 9 & - & 30 & - & 21 & - & 6 \\
\hline & 10 & - & $24 / 67$ & - & 18 / 50 & - & $12 / 33$ \\
\hline \multirow{7}{*}{18} & 1 & 45 & 36 & 0 & 0 & 0 & 0 \\
\hline & 5 & 45 & 36 & 0 & 12 & 0 & 0 \\
\hline & 6 & 45 & 30 & 0 & 15 & 0 & 6 \\
\hline & 7 & 42 & 30 & 7 & 15 & 3 & 6 \\
\hline & 8 & $42 / 93$ & 27 & $16 / 36$ & 22 & $3 / 7$ & 9 \\
\hline & 9 & - & 27 & - & 22 & - & 9 \\
\hline & 10 & - & $21 / 58$ & - & $16 / 44$ & - & $15 / 42$ \\
\hline
\end{tabular}

${ }^{\dagger}$ Data are summarised for three replicates (of each experiment); ${ }^{+}$data at the end of the experiment are highlighted; ${ }^{*}$ the total number of eggs hatched to the present day, including those hatched on the previous days.

ter through the Kerch Strait (Fig. 2). However, ovigerous monogeneans can also be found earlier, during February, when about $40-50 \%$ of them have eggs, and later during autumn (September-November).

The highest values for the indices of both the infection and reproduction of $M$. alosae were observed in specimens of A. immaculata forming pre-spawning schools in Taganrog Bay. Subsequently, when fish migrate into the river, abundance remained high; however, the number of ovigerous monogeneans and their average body size decreased (Fig. 2). Monogeneans have a direct, single-host life cycle, and $M$. alosae lays eggs on the gills of fish, where post-oncomiracidia are also found. All organ systems of an adult are formed at about 15-20 days (Bychowsky 1957). Adult specimens in this study had a body length of $1-12.5 \mathrm{~mm}$, obviously increasing in size with age. Thus, the change in the dynamics of monogenean size mentioned above is likely related to the replenishment of the parasite infrapopulations in the river by young individuals. Therefore, the reproduction of $M$. alosae continues in freshwater.

It is notable that there was a more uniform distribution of monogeneans among shad in the river in comparison with those observed in other regions, which is typical for the initial period of infection of the fish by these parasites. During this period, Pontic shad migrating through the Kerch Strait from the Black Sea to the Sea of Azov were still lightly infected with $M$. alosae and harboured a relatively small number of ovigerous adults, although the parasite infrapopulations were mainly represented by large worms (Fig. 2). In contrast, those shad, which began the return migration through the strait in July, had a high abundance of the parasite, the average size of which was smaller, and ovigerous worms were present in only a third of the infrapopulations. As a result of a decrease in reproduction during this period, combined with the death of the larger (more elderly) monogeneans and, more than likely, the elimination of a proportion of the young specimens, there is a significant decline in the number of $M$. alosae during September-November. During December-January alone, no ovigerous monogeneans were found, and the largest fish that migrate from the Sea of Azov to the Black Sea in December were not infected with the parasite (Fig. 2).

The first study of the influence of shad migration on infection with $M$. alosae was carried out by Kamenev (1953, 1957). This author investigated Alosa immaculata, A. maeotica and A. tanaica in the Black Sea off the Caucasus region and in the Sea of Azov during their spring spawning migration, and also in the Kerch Strait in autumn during the reverse passage of these hosts. Some difference in the proportion of A. immaculata parasitised by M. alosae during spring near the Caucasian coast and elsewhere was recorded, but the infection indices were very low in all samples, i.e. 1-4 fish infected with 1-5 parasites (Kamenev 1953). Similarly, no significant differences were found in the number of monogeneans parasitising the other two shad species (Kamenev 1957). These data contrast markedly with those obtained in the present study, presumably due to the very small fish samples and low monogenean numbers reported by Kamenev $(1953,1957)$ in both of his studies.

On the other hand, when studying seasonal changes in the parasite fauna of $A$. immaculata in the Danube and nearby coastal region of the Black Sea, Petrushevsky (1957) found significant variability in the abundance of $M$. 
alosae. The lowest number of monogeneans was recorded in pre-spawning schools during May, i.e. 13-33\%, with an average infection intensity of $1-2$, and the greatest abundance was among fish leaving the river during summer after spawning (53\% and 1.8 , respectively). This conflicts with the data obtained in the present study (Table 1, Fig. 2). However, it seems likely that, in the northwestern part of the Black Sea basin, the most intensive reproduction of M. alosae occurs in the rivers, whereas, in Pontic shad off the Crimea and migrating into the Sea of Azov, the greatest number of monogenean specimens and eggs per fish were observed during May and June in Taganrog Bay, prior to the shad entering the River Don.

In general, the results of present study are consistent with the data of Bychowsky (1957) in relation to M. alosae on Alosa braschnikowi (Borodin), A. saposchnikowii (Grimm) and A. caspia in the Caspian Sea. Hence, in this inland sea, the reproduction of this monogenean is synchronised with the spawning behaviour of the host, as is the case for shad migrating from the coastal waters of the Crimea to the Sea of Azov. However, in the Caspian Sea, the reproduction of $M$. alosae begins no earlier than the middle of May and lasts for a month, until a time when no ovigerous worms were found. However, nothing is known of the composition of monogenean infrapopulations in the neighbouring freshwater bodies of the Caspian basin, although it is supposed that $M$. alosae may also reproduce in rivers (Bychowsky 1957, Barzegar et al. 2012). Furthermore, the period of reproduction of this monogenean on Pontic shad, which migrate from the Black Sea to the Sea of Azov, is significantly longer and lasts several months (Table 6). It is suggested that this is due to differences in the duration of shad migration to the spawning area and its return.

In the Caspian Sea, the abovementioned Alosa spp. congregate in dense pre-spawning schools in the inshore zone, where some of them spawn in fresh, mainly in the lower reaches, brackish or even marine waters, whereas Pontic shad occurring close to the Crimea congregate in large shoals in the Black Sea and then migrate along coast to the Kerch Strait, prior to passing through the Sea of Azov and into the rivers, up to their middle reaches, and then return in the reverse direction (Svetovidov 1964, Froese and Pauly 2019).

So, in contrast to the Caspian basin, the reproduction of M. alosae in the Black and Azov Seas begins before the shad reach the spawning site. Consequently, the greatest number of monogeneans is recorded in the pre-spawning schools of $A$. immaculata in Taganrog Bay during May, and the average size of these worms is less than in previous months (Table 1), which suggests that infrapopulations of M. alosae have already been replenished by young worms.

It would appear that the abovementioned differences between the results of the present study and those of Petrushevsky (1957), with respect to variation in the abundance of M. alosae associated with fish migration into the River Danube, can be similarly explained. Pontic shad in this region accumulate in dense schools only in the estuarine zone immediately prior to spawning (Svetovidov 1964), similarly to Alosa spp. in the Caspian Sea, and seemingly the reproduction of the monogenean starts during this period and its peak falls at the time when these fish are spawning in freshwater, hence those shad leaving the river are the most heavily infected.

A threefold reduction in the abundance of $M$. alosae during the migration of Alosa fallax from an estuary into a British river has been reported and explained by the smaller size of the fish studied in the river when compared with those from the estuary (Aprahamian 1985). However, the number of monogeneans observed on $A$. immaculata in the River Don and in Taganrog Bay does not differ significantly (Tables 1, 4). Similarly, no variation in the abundance of M. alosae on both A. fallax and Alosa alosa (Linnaeus) was found in different parts of their migration from the coastal waters of the North Sea and the Bay of Biscay to the rivers of France (Gérard et al. 2016, 2017).

A positive influence of host size on the abundance of $M$. alosae has previously been reported (Aprahamian 1985, Gérard et al. 2016, 2017), whereas no correlation between the length of mature specimens of $A$. immaculata and the number of monogeneans harboured was found in the present study. Variation in the abundance M. alosae in the two size groups of adult Pontic shad is the same (Fig. 3) and determined by season. Only non-spawning fish with a total length of up to $13 \mathrm{~cm}$ have a significantly lower level of infection by this parasite.

Previously, it was assumed that shad under the age of two years cannot be parasitised by $M$. alosae, since they were thought to have no contact with adult spawning fish that represented the source of the infection (Bychowsky 1957, Aprahamian 1985, Barzegar et al. 2012). However, M. alosae was found on four species of Alosa Linck at an age of less than one year in studies of the Caspian Sea fauna (Nebolsina 1960), and also a rather high level of infection with this monogenean was reported in immature specimens of two Alosa spp. off the northern coast of France and in French rivers (Gérard et al. 2017). We also found $M$. alosae on $A$. immaculata at an age of less than two years, although the level of infection was relatively low (Table 5). Obviously, immature shad can be parasitised by M. alosae when they are in contact with adult fish in coastal and estuarine waters.

In the Caspian Sea, where the reproduction of M. alosae was recorded in brackish water, tens and even hundreds of monogenean eggs and post-oncomiracidia were found on the gills of shad in the pre-spawning shoals (Bychowsky 1957). Ovigerous specimens of $M$. alosae have also been collected from spawning $A$. fallax caught in freshwater, but neither the eggs and post-oncomiracidia on the gills of these fish nor the development of these eggs were observed. Hence, it has been suggested that reproduction of this parasite in freshwater is unlikely to occur (Finlayson 1981, Aprahamian 1985). Evidence that the development and hatching of the oncomiracidia of $M$. alosae are not limited by the low salinity of the water was obtained for the first time during the present study. Moreover, in addition to the experimental data, we found newly settled post-on- 
comiracidia on the gills of Pontic shad caught in the River Don during May.

Hence, the main factor affecting the dynamics of the abundance of $M$. alosae is season. The life-history of this parasite is strongly synchronised with the duration of the host's migration from Crimean coastal water through the
Sea of Azov and into rivers for spawning, and the reproduction of this monogenean occurs in both in fresh and seawater.

Acknowledgement. This work was supported by project AAAA-A18-118020890074-2 of the Ministry of Science and Higher Education of the Russian Federation.

\section{REFERENCES}

Aprahamian M.W. 1985: The effect of the migration of Alosa fallax fallax (Lacépède) into fresh water, on branchial and gut parasites. J. Fish Biol. 27: 521-532.

Bao M., Roura A., Мota M., Nachón D.J., Antunes C., Совo F., MacKenzie K., Pascual S. 2015: Macroparasites of allis shad (Alosa alosa) and twaite shad (Alosa fallax) of the Western Iberian Peninsula rivers: ecological, phylogenetic and zoonotic insights. Parasitol. Res. 114: 3721-3739.

Barzegar M., Bozorgnia A., Youssefi M.R., Hosseinifard S.M. 2012: Determination of Alosa caspia persica parasites in fresh and brine water of Caspian Sea. World J. Fish Mar. Sci. 4: 175-178.

Bychowsky B.E. 1957: [Monogenetic Trematodes, Their Systematics and Phylogeny.] Nauka, Moscow-Leningrad, 509 pp. (In Russian.)

Chernishenko A.C. 1955: [Data on parasite fauna of fishes of Odessa Gulf.] Trudy Odessa Univ. 145: 211-222. (In Russian.)

Chernova T.N. 1975: [The influence of the salt regime of Lake Paleostomi on the fish parasitic fauna.] Trudy VNIRO 105: 121127. (In Russian.)

Dimitrov G.I. 1989: Investigation of helminths from fishes off Bulgarian coast of the Black Sea. Unpublished PhD Thesis, Bulgarian Academy of Sciences, Sofia, $35 \mathrm{pp}$.

ISAYCHIKOV I.M. 1925: [Working of the parasitological laboratory in fishing expedition in the Sea of Azov in 1922.] Trudy Sib. Vet. Inst. 6: 19-46. (In Russian.)

FINLAYSON J.E. 1981: The biology of the mazocraeid gill parasites of mackerel, sprat and shad. PhD Thesis, University of Birmingham, UK. (cited after Aprahamian 1985).

Froese R., Pauly D. (Eds.) 2019: FishBase. World Wide Web electronic publication, www.fishbase.org, 06/2019.

Gérard C., Hervé M., Réveillac E., Acou A. 2016: Spatial distribution and impact of the gill-parasitic Mazocraes alosae (Monogenea, Polyopisthocotylea) on Alosa alosa and A. fallax (Actinopterygii, Clupeidae). Hydrobiologia 763: 371-379.

Gérard C., Hervé M., Gay M., Bourgau O., Feunteun E., Acou A., RÉveillac E. 2017: Metazoan parasite communities in Alosa alosa (Linnaeus, 1758) and Alosa fallax (Lacépède, 1803) (Clupeidae) from North-East Atlantic coastal waters and connected rivers. Parasitol. Res. 116: 2211-2230.

Gusev A.V. 1983: [Methods of Collection and Processing Material of Monogeneans Parasitizing Fish.] Nauka, Leningrad, 47 pp. (In Russian.)

Kamenev V.P. 1953: [On changes in the parasitic fauna of Pontic shad Caspialosa kessleri pontica due to migration.] Uchen. Zap. Krasnodarsk. Pedagog. Inst. 11: 16-23. (In Russian.)

Kamenev V.P. 1957: [On changes in the parasitic fauna of shad Caspialosa brashnicovi maeotica and C. caspio tanaica due to migration.] Uchen. Zap. Krasnodarsk. Pedagog. Inst. 19: 19-26. (In Russian.)
Korshenko A. (Ed.) 2017: [Marine Water Pollution Annual Report 2016.] Nauka, Moscow, 285 pp. (In Russian.)

Lenhardt M., Navodaru I., Vassilev M., Kalauzi A., RegNer S., Višnuić-Jeftić Ž., Tošić K., SmederevaC-Lalić M. 2016: Model of the Pontic shad Alosa immaculata (Bennett, 1835) and anchovy Engraulis encrasicolus (Linnaeus, 1758) catch in the Danube River and Black Sea for the period 1920-2008. Acta Zool. Bul. 68: 557-561.

Lia R.P., Zizzo N., Tinelli A., Lionetti A., Cantacessi C., Otranto D. 2007: Mass mortality in wild greater amberjack (Seriola dumerili) infected by Zeuxapta seriolae (Monogenea: Heteraxinidae) in the Ionian Sea. Bull. Eur. Assoc. Fish Pathol. 27: 108-111.

Nebolsina T.K. 1960: [Infection of young fish of the Caspian species of Alosa with the trematode Mazocraes alosa.] Dokl. Akad. Nauk SSSR 131: 1478-1480. (In Russian.)

Osmanov S.U. 1940: [Materials on the parasite fauna of the Black Sea fishes.] Trudy Leningr. Pedagog. Inst. 30: 187-266. (In Russian.)

ÖZer A., Öztürk T., Korniychuk J. 2013: First report of Mazocraes alosae (Herman, 1782), Pronoprymna ventricosa (Rudolphi, 1891) and Lecithaster confusus Odhner, 1905 in Pontic shad Alosa immaculata Bennet, 1835 near Turkish coasts of the Black Sea. Lucrări Ştiinţifice, Seria Zootehnie 59: 311-314.

Paskevichute A.C. 1971: [Monogeneans from the downstream of the rivers of the northwestern part of the Black Sea basin.] Gidrobiol. Zh. 7: 56-60. (In Russian.)

Pogorel'tseva T.P. 1952: [Data on parasite fauna of fishes in the North-Western part of the Black Sea.] Pratsi Inst. Zool. 8: 100120. (In Ukrainian.)

POPYUK M.P. 2009: [Helminth fauna of pelagic fishes off Crimea (Black Sea).] Ecol. Morya 78: 75-80. (In Russian.)

POPYUK M.P. 2011: [Parasite fauna of three species of mass pelagic fish during migration through the Kerch Strait.] Ecol. Morya 18: 73-80. (In Russian.)

Petrushevsky G.K. 1957: [Parasite fauna of clupeid fishes of the Black Sea.] Izv. VNIORKH 42: 304-314. (In Russian.)

Roman E. 1956: [New contributions to our knowledge of the monogenean fauna of the RomanianP.R.] Comunicarile Academiei R.P.R. 6: 133-144. (In Romanian.)

Rubio-Godoy M. 2007: Fish host-monogenean parasite interactions, with special reference to Polyopisthocotylea. In: L.I. Terrazas (Ed.), Advances in the Immunobiology of Parasitic Diseases. Research Signpost, Trivandrum, pp. 91-109.

Solonchenko A.I. 1982: [Helminth fauna of fishes in the Sea of Azov.] Naukova Dumka, Kiev, 150 pp. (In Russian.)

Svetovidov A.N. 1964: [Fishes of the Black Sea.] Nauka, Moscow-Leningrad, 553 pp. (In Russian.) 